\title{
Ko nipa Africa! - Teach about Africa! Challenging stereotypes about Africa
}

\author{
MARIANNA KÁRMÁN ${ }^{1 *}$ (i) and NÓRA MÁRFÖLDI²
}

\author{
${ }^{1}$ Doctoral School of Safety and Security Studies of Óbuda University, African Research Institute, \\ Budapest, Hungary \\ ${ }^{2}$ Eötvös Loránd University Faculty of Primary and Pre-School Education, Budapest, Hungary
}

\section{RESEARCH ARTICLE}

Received: May 29, 2021 • Accepted: July 8, 2021

Published online: November 15, 2021

(c) 2021 The Author(s)

\begin{abstract}
Designed for three age groups, Ko Nipa Africa! - Teach about Africa! awareness-raising and sensitization education program is aimed at developing social competencies, especially empathy, social sensitivity, and tolerance in childhood. In addition, its main task is to transform the misconceptions and prejudices about Africa present in Hungary with active learning. The series of programs seeks to bring the diverse cultural, natural, and historical values of the African continent closer to the younger generation using the approach of global education, and the method, and tools of experiential pedagogy. Since the founding of the program series in 2012, it has been tested, implemented, and reworked in dozens of educational institutions, and several studies have demonstrated positive changes in students' thinking as the result of sensitization.
\end{abstract}

\section{KEYWORDS}

global education, sensitization program, teaching methods, social competence, African culture, experiential pedagogy

\section{INTRODUCTION}

In response to the conflicts of globalization, pedagogy has created a new approach called global education. This view conveys the knowledge, attitudes, competencies, and values needed to

\footnotetext{
*Corresponding author. E-mail: karman.marianna@phd.uni-obuda.hu
} 
create a fairer and more sustainable world (Artemisszió Alapítvány, 2014). It aims to promote an understanding of the complex problems that exist in the world, to support learners to become critical, sensitive, and active citizens, and to develop responsibility for future generations. It is important for students to see themselves as part of the global world, to see their roles, duties, and shared responsibilities, and to take responsibility for the protection of their wider environment. Its personality-forming effect and its prominent role in the development of social competence should also be emphasized. Global education enables cooperation, tolerance, empathy, and openness to accepting otherness (Havas, 1994).

Global education is an interdisciplinary field that includes several fields of education. Including education against racism and sexism, education for sustainability, multi- and intercultural education, education for peace, education for human rights, education for solidarity, education for democracy, media education and environmental education (Cates, 1995; HAND Globális Nevelés Munkacsoport, 2008).

In Hungary, even though the declared goal to teach a global approach is included in the National Core Curriculum since 2012, the implementation is often lacking in traditional education. One of the reasons for the shortcoming is, on the one hand, that the established frontal education is only suitable in exceptional cases for the implementation of global education. On the other hand, many educators are not trained in the methodology of global education, and/or it involves too much additional burden for them to involve experts from one field or another to discuss the topics. Therefore, initiatives created primarily by NGOs (training, participation in kindergarten/school activities, educational materials) are still the only real solution. However, the disadvantage of these is that most of them are only work in the short term, and their funding and their integration into education is difficult to accomplish, thus their results are also hard to monitor.

Implementation may seem difficult, although to create a global education we do not need to override the traditional practice of teaching, we do not need to create a completely new school subject. In every existing one, we can find a connection point with our globalized world. Thus, the best solution is for each subject to have a global perspective to support students' preparation for the challenges of the future (Anthropolis Egyesület, 2019).

In today's multicultural, multilingual society, it is essential to embrace skills such as respect and acceptance of others in order to create peaceful coexistence, work effectively or solve global problems together. Education plays a key role in this. If we want to prepare children for the future, as one of the founders of reform pedagogy, John Dewey, put it back in 1938, the development of social competencies, acceptance of diversity, multicultural education, active and responsible citizenship education should be included in institutional education.

\section{THE PROGRAM}

The Ko nipa Africa! - Teach about Africa! educational program was established in 2012 in accordance with the approach mentioned above, with the aim of promoting the culture of the African continent and its research among children living in Hungary.

The educational program was named in the Nigerian Yoruba language used in the founder's primary research field: ko nipa Africa, which means 'taníts Afrikáról' in Hungarian ('teach (me) about Africa' in English). Utilizing the semantic double meaning of the Hungarian name, the 
program series formulates the children's needs: teach me about Africa and draws teachers' attention to a popular but stereotyped area, the teaching of topics related to the African continent and its benefits. The bilingual name was based on the cooperation with Nigeria and raise awareness of African languages.

The founder of the program, dr. Marianna Kármán is an Africanist who created the program with the aim of ensuring the supply of African research in Hungary. In the life of Hungarian science, the topic of Africa was forgotten after the change of regime, no research institutes were established within the academic framework, therefore research on the topic was infrequent, and universities were still unable to establish an independent course about Africa - The African Studies program at the Faculty of Arts of Eötvös Loránd University, founded by dr. Géza Füssi Nagy ceased in 2007 with the death of the founder.

Ignoring the continent, which includes 54 countries and thousands of peoples, would certainly be a folly in scientific life, as in addition to the interest of researchers in many disciplines, political and economic relations have also come to the forefront of attention in recent years in relation to Africa, also referred to as the continent of the future.

One of the most important principles of the founder was to make the educational program as widely available and free of charge as possible to public institutions. Although the educational project was launched on a simple professional and voluntary basis, the Anthropolis Egyesület soon recognized the potential of such a series of programs and contributed both professionally and financially to launching a program that favored regular contact with both children and institutions rather than the occasional lectures on Africa.

Thus, in the 2012/2013 school year, the kindergarten program started on an experimental basis in one of the groups of the Hársfa Kindergarten in Kispest, with the professional participation of the kindergarten's master teacher. Later other professionals and volunteers joined the project, so the children could be educated in extremely varied ways already in the experimental phase. In addition to the kindergarten program, on the propose of the Anthropolis Egyesület, the educational project also appeared in primary school education. Even in the first school year, two classes of the Eötvös József Primary School in Kispest joined the program.

In the absence of support, the program series was continued on a voluntary basis in the partner kindergarten. In addition to the founder, volunteers and assistants continued their work in the program in the first year, and teachers and volunteers of African descent living in Hungary also joined the project.

From 2017, the African-Hungarian Union (AHU) has made it possible for the educational program to become known nationally, as well as to implement alternative lessons that also fit into the National Core Curriculum. The activities of the association also became popular among educators, several of them volunteered to implement the African-Hungarian Union's (AHU) goals in Hungary, but there were educators who introduced the African reality to their class through the child support programs in Mali.

The Ko nipa Africa! - Teach about Africa! education program has taken many forms over the years and, in addition to the regular curriculum, has provided an opportunity to hold Africanthemed lessons, incorporating the African theme as an educational aid for children with learning difficulties and disabilities.

The program was revised in 2019 as part of the "Empathy Challenge" of the UKids international research and development project for 5th grade students by Nóra Márföldi.

The goals of the program include: 
-sensitizing the given children's community to minorities, improving their sense of acceptance; -expanding children's cultural knowledge;

-setting up educational models for public institutions with the involvement of teachers;

-transforming parents and the population into a more inclusive community through a multilevel intercultural dialogue;

-development and introduction of the multicultural education model implemented in the institutions to other non-governmental organizations;

-the involvement of non-governmental organizations with a similar profile in the project in order to exchange experiences and establish cooperation;

-development of organizational networks at regional/national level.

The program targets three age groups:

-students who are in the early stages of schooling or those children, who are preparing for school

-primary school students who have been learning English for 3 years;

-high school students who are about to choose a career.

The kindergarten project primarily aims to impart basic knowledge on topics related to the African continent. Classes introduce children to Africa in the morning, on a weekly or fortnightly basis, throughout the school year. On the occasion of the projects implemented so far, a kindergarten group participated in an average of 10-15 sessions, at the end of the program the children reported on the knowledge gained during the program in a playful way: either they made a poster about Africa in small groups (4-6 people) or they presented their knowledge of Africa in the form of a lecture for parents. At the end of each school year, the children filled out worksheets, which made it possible to track the kindergarteners' knowledge of the African continent.

The primary school project is also a project that runs throughout the school year, with a twosemester thematic division. As part of the home classes, the project lecturer gives lectures every two weeks on Africa, then specifically on Nigeria in the first semester. In the second semester they start to communicate with African immigrants in English. They have the opportunity to correspond with students living in Nigeria and talk to the speaker about issues that arise during their correspondence and events related to the lives of Nigerian students. In addition to highlighting the differences, special emphasis is placed on the similarities between the two cultures in order to reduce children's sense of distance from the African culture. These similarities can even be as abstract concepts as fair play. As Gabriella Hideg's study reveals, the opinion of the interviewed Hungarian and Kenyan children is almost the same about the assessment of fair play (Hideg, 2019).

For both age groups, one of the main objectives of the project is to create a realistic image of Africa in children, free from prejudices or overidealized images. Comparing foreign cultures with one's own culture, developing identity by developing similar and differentiating thinking.

The high school project, which is being implemented, no longer focuses on identity formation, but on professionalism. Students can deal with African topics in a non-compulsory but elective form, where representatives of each discipline give a presentation on a project related to Africa in the field of research they represent. Disciplinary sessions are held weekly with the involvement of specialist teachers, who also seek to incorporate the African topic, which has 
been omitted from the current secondary school curriculum, into the lesson material they will teach in the future after the project. During the project, students will have the opportunity to gain insight into different levels of academic life, get acquainted with renowned representatives of each discipline, and learn about career, professional and labor market opportunities related to their chosen field, regardless of the topic.

To implement the high school program, both high school and university partnerships were established before the outbreak of the pandemic.

\section{THE STUDY}

\section{Sample}

Table 1. Ko nipa Africa! - Teach about Africa! program series implementations data

\begin{tabular}{|c|c|c|c|c|c|}
\hline $\begin{array}{l}\text { Date of the } \\
\text { program }\end{array}$ & $\begin{array}{c}\text { Frequency and } \\
\text { number of } \\
\text { hours }\end{array}$ & Place & $\begin{array}{c}\text { Age and } \\
\text { number of } \\
\text { participants }\end{array}$ & Form of activity & Supported by \\
\hline $\begin{array}{l}\text { 2012/2013. } \\
\text { school year }\end{array}$ & $\begin{array}{c}45-60 \mathrm{~min} \\
\text { every two } \\
\text { weeks for a } \\
\text { total of } 8 \text { times }\end{array}$ & $\begin{array}{c}\text { Hársfa } \\
\text { Kindergarten, } \\
\text { Budapest }\end{array}$ & $\begin{array}{l}5-7 \text { year olds, } \\
28 \text { people }\end{array}$ & $\begin{array}{l}\text { program series } \\
\text { in the form of } \\
\text { morning group } \\
\text { sessions }\end{array}$ & $\begin{array}{c}\text { Anthropolisz } \\
\text { Egyesület }\end{array}$ \\
\hline $\begin{array}{l}\text { 2012/2013. } \\
\text { school year }\end{array}$ & $\begin{array}{l}45 \text { min every } \\
\text { two weeks for a } \\
\text { total of } 4-4 \\
\text { times }\end{array}$ & $\begin{array}{l}\text { Eötvös József } \\
\text { Primary School } \\
\text { in Kispest, } \\
\text { Budapest }\end{array}$ & $\begin{array}{l}12-15 \text { year } \\
\text { olds, } 60 \text { people }\end{array}$ & $\begin{array}{l}\text { program series } \\
\text { as part of home } \\
\text { classes }\end{array}$ & $\begin{array}{c}\text { Anthropolisz } \\
\text { Egyesület }\end{array}$ \\
\hline $\begin{array}{l}\text { 2014/2015. } \\
\text { school year }\end{array}$ & $\begin{array}{c}45-60 \mathrm{~min} \\
\text { every two } \\
\text { weeks for a } \\
\text { total of } 12 \text { times }\end{array}$ & $\begin{array}{c}\text { Hársfa } \\
\text { Kindergarten, } \\
\text { Budapest }\end{array}$ & $\begin{array}{l}\text { 5-7 year olds, } \\
27 \text { people }\end{array}$ & $\begin{array}{l}\text { program series } \\
\text { in the form of } \\
\text { morning group } \\
\text { sessions }\end{array}$ & $\begin{array}{l}\text { Ibn Khaldún } \\
\text { Alapítvány }\end{array}$ \\
\hline $\begin{array}{l}\text { 2017/2018. } \\
\text { school year }\end{array}$ & $\begin{array}{l}45 \text { min every } \\
\text { two weeks for a } \\
\text { total of } 8-8 \\
\text { times }\end{array}$ & $\begin{array}{l}\text { Eötvös József } \\
\text { Primary School } \\
\text { in Kispest, } \\
\text { Budapest }\end{array}$ & $\begin{array}{c}12-13 \text { year } \\
\text { olds, } 60 \text { people }\end{array}$ & $\begin{array}{l}\text { program series } \\
\text { as part of home } \\
\text { classes }\end{array}$ & $\begin{array}{l}\text { African- } \\
\text { Hungarian } \\
\text { Union }\end{array}$ \\
\hline $\begin{array}{l}\text { 2017/2018. } \\
\text { school year }\end{array}$ & $\begin{array}{c}45 \text { min every } \\
\text { two weeks for a } \\
\text { total of } 10-10 \\
\text { times }\end{array}$ & $\begin{array}{c}\text { Batthyány } \\
\text { Fülöp } \\
\text { Grammar } \\
\text { School and } \\
\text { Primary School, } \\
\text { Enying }\end{array}$ & $\begin{array}{c}\text { 7-9 year olds, } \\
30 \text { people } \\
10-12 \text { year } \\
\text { olds, } 30 \text { people } \\
13-14 \text { year } \\
\text { olds, } 30 \text { people }\end{array}$ & $\begin{array}{l}\text { program series } \\
\text { as part of home } \\
\text { classes }\end{array}$ & $\begin{array}{l}\text { African- } \\
\text { Hungarian } \\
\text { Union }\end{array}$ \\
\hline $\begin{array}{l}\text { 2017/2018. } \\
\text { school year }\end{array}$ & $\begin{array}{l}45 \text { min every } \\
\text { two weeks for a } \\
\text { total of } 15 \text { times }\end{array}$ & $\begin{array}{l}\text { Budafok- } \\
\text { Tétényi Baross } \\
\text { Gábor Primary } \\
\text { School in } \\
\text { Budafok- } \\
\text { Tétény, } \\
\text { Budapest }\end{array}$ & $\begin{array}{l}7-9 \text { year olds, } \\
30 \text { people }\end{array}$ & $\begin{array}{l}\text { program series } \\
\text { as part of home } \\
\text { classes }\end{array}$ & $\begin{array}{l}\text { African- } \\
\text { Hungarian } \\
\text { Union }\end{array}$ \\
\hline
\end{tabular}


Table 1. Continued

\begin{tabular}{|c|c|c|c|c|c|}
\hline $\begin{array}{l}\text { Date of the } \\
\text { program }\end{array}$ & $\begin{array}{c}\text { Frequency and } \\
\text { number of } \\
\text { hours }\end{array}$ & Place & $\begin{array}{c}\text { Age and } \\
\text { number of } \\
\text { participants }\end{array}$ & Form of activity & Supported by \\
\hline $\begin{array}{l}\text { 2017/2018. } \\
\text { school year }\end{array}$ & $\begin{array}{l}45 \text { min every } \\
\text { two weeks for a } \\
\text { total of } 5 \text { times }\end{array}$ & $\begin{array}{c}\text { Wesley János } \\
\text { Kindergarten, } \\
\text { Budapest }\end{array}$ & $\begin{array}{l}5-7 \text { year olds, } \\
20 \text { people }\end{array}$ & $\begin{array}{l}\text { program series } \\
\text { in the form of } \\
\text { morning group } \\
\text { sessions }\end{array}$ & $\begin{array}{l}\text { African- } \\
\text { Hungarian } \\
\text { Union }\end{array}$ \\
\hline $\begin{array}{l}\text { 2018/2019. } \\
\text { school year }\end{array}$ & $\begin{array}{c}45 \text { min every } \\
\text { two weeks for a } \\
\text { total of } 15 \text { times }\end{array}$ & $\begin{array}{c}\text { Hársfa } \\
\text { Kindergarten, } \\
\text { Budapest }\end{array}$ & $\begin{array}{l}\text { 5-7 year olds, } \\
30 \text { people }\end{array}$ & $\begin{array}{l}\text { program series } \\
\text { in the form of } \\
\text { morning group } \\
\text { sessions }\end{array}$ & $\begin{array}{l}\text { African- } \\
\text { Hungarian } \\
\text { Union }\end{array}$ \\
\hline $\begin{array}{l}\text { 2018/2019. } \\
\text { school year }\end{array}$ & $\begin{array}{c}45 \text { min every } \\
\text { two weeks for a } \\
\text { total of } 10 \text { times }\end{array}$ & $\begin{array}{l}\text { Tündérkert } \\
\text { Kindergarten, } \\
\text { Halásztelek }\end{array}$ & $\begin{array}{l}\text { 5-7 year olds, } \\
30 \text { people }\end{array}$ & $\begin{array}{l}\text { program series } \\
\text { in the form of } \\
\text { morning group } \\
\text { sessions }\end{array}$ & $\begin{array}{l}\text { African- } \\
\text { Hungarian } \\
\text { Union }\end{array}$ \\
\hline $\begin{array}{l}2019 / 2020 . \\
\text { school year }\end{array}$ & $\begin{array}{c}45 \mathrm{~min} \text { per } \\
\text { week for a total } \\
\text { of } 8 \text { times }\end{array}$ & $\begin{array}{c}\text { Lázár Ervin } \\
\text { Primary School, } \\
\text { Budapest }\end{array}$ & $\begin{array}{c}10-11 \text { year } \\
\text { olds, } 20 \text { people }\end{array}$ & $\begin{array}{l}\text { program series } \\
\text { as part of home } \\
\text { classes }\end{array}$ & $\begin{array}{c}\text { African- } \\
\text { Hungarian } \\
\text { Union, Ukids }\end{array}$ \\
\hline
\end{tabular}

\section{Method}

We wondered what preconceived notions children had about Africa, the people living there, and whether these stereotypes and preconceptions could be changed because of a series of thematic programs. We hypothesized that due to the ideas about Africa appearing in the Hungarian society, and education system, students and children associate negative concepts with Africa, and their knowledge is one-sided. We examined the students' preconceptions about Africa, their knowledge, and attitudes before, during, and after the series of sessions. Prior to the start of the programs, we conducted a semi-structured interview with the class teachers and kindergarten teachers of the group/class participating in the program to learn more about the composition of the group. The prior knowledge structure mapping was done using free word association tests, observations, focus group interviews, and projective drawing tests. Pedagogical reflections were made on the lessons of the program, which were analyzed according to a system of criteria. The results were documented by scientific methods. Among the quantitative methods, we conducted a questionnaire research to assess the changes in the level of knowledge and attitudes of students and children as a result of the program. Their results were processed and analyzed using SPSS 20.0 statistical analysis software.

\section{RESULTS}

\section{Case studies and experiences of the kindergarten program}

The kindergarten program was implemented in a total of three kindergartens: the Hársfa in Kispest, the Tündérkert in Halásztelek and the Wesley János Kindergarten in Budapest. 
Ko nipa Afrika! - Teach about Africa! started operating first in the Hársfa Kindergarten in Kispest. After consultation with the director of the institution, with the professional support of the kindergarten master teacher, the program was held in a mixed group for children aged 5-7, within the framework of the morning session.

For the first time, the speaker surveyed children's knowledge of Africa and then used pictures to present Africa's diverse culture. They operated with concepts that are familiar to children (and which are based on stereotypes): skin color, clothing, geographical features (desertsavannah-rainforest). The first lesson was about breaking down these stereotypes. The second time was connected to this, which specifically presented the diverse lives of African children regardless of ethnicity or social background.

The structure of the sessions always took into account the children's age, ability to concentrate. It was divided into two parts: an interactive presentation and a subsequent playful table or movement tasks. During the interactive lectures, the presenter presented all the information with the help of illustrated pictures or objects. They involved the children in a conversation where the preschoolers could share their thoughts and experiences related to the topic. The workload of children using these tools and methods has increased to an extent that can be expected at primary school age. The exoticism of the topic, the emotional identification with each situation, the opportunity for playful learning brought out a performance from all participants in the program that was not only acknowledged by the educators involved, but also confirmed by the feedback from the parents.

The annual theme was also adapted to the age-appropriate development opportunities of the children, so every third craft sessions were interspersed with the transfer of information about the continent, where there was an opportunity for informal conversation.

In the fourth and fifth sessions, the lecturer introduced the fauna of Africa during the student screening. It was then that the children had the opportunity to stand up to their contemporaries for the first time and recount essentially their favorite African animals in three to four sentences. The children learned to introduce a topic that was important to them, to justify their claims, and to ask questions of each other by listening to each other.

From the sixth lecture, the children got acquainted with the diverse culture and social difficulties of Africa. The rhythm of the African language, the world of African musical instruments, African food, traditional costumes, ornaments, folk customs always aroused deep interest in the children. By getting to know a foreign culture, they also got to know their own culture, and they were able to compare African and Hungarian traditions. They could get hold of African instruments, try them out, form a band, dance and sing. They could taste African vegetables and fruits themselves.

From the 2014/15 school year, volunteers from Togo, Tanzania, Angola, Congo and Nigeria also came on one or more occasions to help with the sessions as an assistant or with a musicdance performance. With the exception of the Tanzanian volunteer, the others did not speak Hungarian, so it was especially interesting for the children to make contact with them. They taught African volunteers Hungarian words, and they also asked many questions about the volunteers' mother tongue.

The children were interested in the topic in all three institutes, there were no disciplinary problems, children aged five or older joined the session, several kindergarteners were actively involved in the sessions. 
The performances at the Wesley János Kindergarten ended with an African-themed Santa Claus ceremony, the year ended with a playful knowledge level measurement at the Hársfa Kindergarten, a drama pedagogical session in the second year, and a music-dance performance in the third year. In the Tündérkert Kindergarten, the African-Hungarian Union (AHU) held a complex Africa Day for the whole kindergarten including parents.

\section{Case studies and experiences of the primary school program}

The primary school program started with a number of difficulties. Although there was not enough capacity at first, several schools joined the program from the 2017/2018 school year. We held classes every two weeks as part of the home class in a total of six classes. As the age groups of the class cohorts were different ( $2 \mathrm{~s}$, one fifth, two sixth and one eighth grade classes), the lecturer passed on the topics of the lectures to the children with a depth of knowledge appropriate to the age groups.

The primary school students followed the kindergarten theme, while middle schoolers participated in a series of programs focused on Nigeria. After an introductory lecture on Africa and a playful assessment of their knowledge, middle school students learned about Nigeria's history, geography, fauna and flora, culture and traditions, languages, literature, religions, and major social difficulties. Due to the communication difficulties of the Nigerian partner school, the correspondence program planned for the project between Hungarian and Nigerian students was not implemented, but they had the opportunity to meet Africans living in Hungary and ask them questions in Hungarian or English.

The second class of the Baross Gábor Primary School participated in in the alternative programs of the project for three years. They were the first to take part in the Africanthemed board game show, to visit the Nigerian Artmosphere exhibition organized by the African-Hungarian Union (AHU), and to participate in an art workshop organized by the association. They took part in a sightseeing walk in Budapest, where they followed lions, the most popular predator of Africa and one of the most common decorative animal figures in buildings in Budapest. The enthusiasm of the class is shown by the fact that at the end of the program, they wrote and perform their own performance about Africa, in which they presented their favorite animals, they talked about Kenya and the Maasai, and they performed Maasai dances using African instruments as musical accompaniment. It is important to mention that it was primarily the educator's merit that the children were able to work so independently and in a disciplined manner, and their interest in and openness to the topic allowed them to take a high-quality performance to the stage.

The Eötvös József Primary School in Kispest has also developed a multifaceted partnership over the years. The start of the extraordinary lessons at this institution began with the holding of a literature class where students could learn about the elements of African drama. They may have come across linguistic and literary concepts that European literature does not know or cannot interpret. The speaker also introduced students to writing systems other than the Latin letter. Unusual classes were later held within the framework of the History, Music and Visual Art Class. Students in the school's drawing department also attended an art workshop linked to the Nigerian Artmosphere exhibition. 


\section{Case studies and experiences with regards to special occasions}

As the funding and human resources of the program allowed only a limited number of applicants to be admitted to the program series, in addition to the partner institutions, one or more than one day African programs were held in 17 public education and one public institution within the framework of Ko nipa Africa! - Teach about Africa! educational program.

In the summer of 2017, through the African-Hungarian Union (AHU), the program also reached the outpatient day camp of the Child and Adolescent Psychiatric Rehabilitation Department of Szent János Hospital, where we first recognized the special opportunities inherent in the educational program. Among the programs tailored to the needs of the children participating in the camp, with the help of educators and professionals, we were always able to choose options that engaged the given age group or children with special needs. African instruments, music, and dance even made children, for whom moving and participating was especially difficult, attend these activities.

In the autumn of 2017, a team of African and Hungarian volunteers visited the Dr. Török Béla Primary School in Budapest, with the support of the African-Hungarian Union, where we held classes for hearing-impaired children. During the introductory and educational presentation introducing the program, we were already very interested, and despite the participants of different ages, the dialogue between the children and the presenter was easily established. More than 100 students from the school took part in the Africa Day organized for the school. At the tables set up in the dining room, a shaker could be made using the decoupage technique, and the more patient children could fold African animals out of paper. For the little ones, the school's educators and association volunteers provided countless African-themed activities from coloring through the jigsaw puzzle to the cut-out snake ring. After the craft classes, the kids had a treat from a Nigerian puff-puff made by the school's canteen, and then the long-awaited instrument demonstration began. We took different types of drums and rhythm instruments from many parts of Africa, which the children were very happy to try. Astonishment and excitement peaked with the performance of the Serengeti Troupe band. The children danced liberally and enthusiastically to the rhythm of the drums, and the braver ones accompanied the band with the instruments they learned at the instrument show, and at the end of the performance they could go up the stage to touch the congas. The number of tiny hands per drum surface sometimes reached ten, yet there was no scramble, only music playing together and eyes gleaming with happiness looking at each other.

As the year-end event of the 2018/2019 school year, Ko nipa Africa! - Teach about Africa! educational program also reached Polgárd, where we held learning methodology training days for sixth graders at the Széchenyi István Primary School. The children were able to learn the theoretical foundations of the learning methodology, which we made special with examples chosen from African educational traditions and by solving African-themed tasks, such as e.g. they had to learn a poem titled Mihály Babits: Africa, Africa, or they had to make a summary of African tales in small groups. Board games of African origin or with an African theme have played a major role in the development of logical and strategic thinking. Once again, the instruments were a great help in shaping the community and paying attention to each other. For the spontaneous performance of a piece of music, it is always necessary for the participants to work together as a team, to pay attention to each other, to respect and help each other. The success of the program was demonstrated by the close cooperation with the institution, and the 
children participated actively, successfully and enriched on the last day of the school year, despite their learning difficulties.

Interactive elements related to the program: instrument demonstrations, craft classes, African board games, folk costumes or African food demonstrations provided an alternative opportunity to develop individual competencies early in the program. Therefore, in addition to educational institutions, we have provided program opportunities for children in many areas throughout the country. Institutions dealing with children (eg. museums, zoos, houses of culture, libraries) have continuously used Ko nipa Africa! - Teach about Africa! since 2017, which made it possible for the initiative to become even more widely known.

\section{Case studies and experiences with regards to the continuation of the program}

The program was implemented in 2019 as part of the Ukids international project ("Youth Start" Social Entrepreneurship Program for Kids), which aims to educate "everyday heroes," i.e., develop social entrepreneurship at an early school age. The program builds on thematic challenges to develop students 'entrepreneurship through active learning. Among the challenges, during the Empathy Challenge, 5th grade students participated in the enhanced Ko Nipa Africa! - Teach about Africa! program series.

The participants of the sensitization program were 5th grade (10-11 years old) students of Lázár Ervin Primary School located in the outer district of Budapest, who got acquainted with the diverse geography, culture, and problems of the continent through eight sessions.

Prior to the start of sensitization program, a semi-structured interview with the class teacher of the class participating in the program gave an insight into the class community formed so far, the pedagogue's approach and educational strategy. Students 'preconceptions about Africa, their knowledge and attitudes were examined before, during, and after the series of sessions. To map children's prior attitude and level of knowledge about the African continent and people, we used two methods together: a projective drawing test, in which students had to draw an African child, and a free word association where they had to write five phrases in relation to the buzzword, Africa. The results of the methods assessing the children's prior knowledge showed prejudices in their image of Africa, and the sense of social distance they felt.

Most often, and for the first time, terms related to geography came to their mind, but negative associations with the concepts of poverty, disease, and hunger also appeared with high frequency. Terms related to brown skin included words with generally negative, pejorative meanings such as "feka," "nigger," and "néger" (Fig. 1).

During the projective drawing test, with one exception, a brown skin color appeared in all children's drawings. In 16 student's drawings of the African children, the child does not wear footwear, his clothes are often torn, swinging, or completely missing, which can be clearly identified with poverty. During the classes, it has become clear to us on several occasions that they identify Africa primarily with one-sided images seen in the media, where everyone is sick, poor, has brown skin and lives in a hut. Moreover, many did not know that Africa is a continent and not a country.

Among the quantitative methods, we conducted a questionnaire research method to assess the students' changes in knowledge levels and attitudes as a result of sensitization The research also looked at the relationship between students' attitudes towards Africa and their attitudes towards other peoples, and the students' self-image based on their own self judgment (primarily 


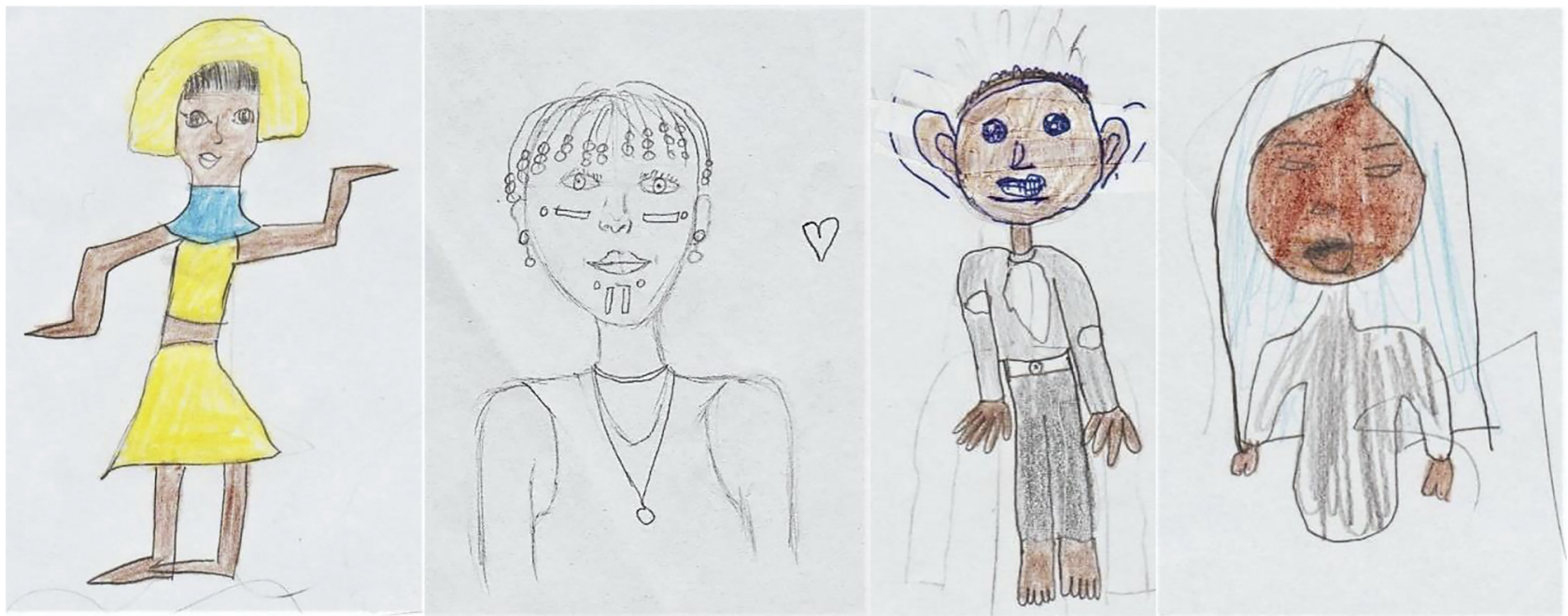

Fig. 1. Selection of African children's drawings made during the projective drawing test 
in terms of tolerance and empathy). Based on the questionnaire analysis, it can be stated that the students' preconceptions and knowledge about Africa changed in a positive direction as a result of the program. In the multiple-choice tasks of the questionnaire, students correctly judged the truthfulness of the statements compared to the experience of previous tests and occupations.

The children identified that the distance between them and African children were as small as if they were deskmates. This was shown via Morgan's Shared Activities Questionnaire (Morgan, Walker, Bieberich, \& Bell, 1996). The study shows that students would be happy if their friend would be an African child, so their sense of social distance towards them is low. They feel they bear the responsibility of the well-being of Africans. They believe their problems are our problems too.

To examine the class's image of Africans, children evaluated six personality trait pairs (see Table 2). Pupils had a positive opinion of those living on the continent, as evidenced by the high average values (6-8). African children were highly rated for their helpful, friendly, and peaceful quality. $64 \%$ of the students rated the characteristics of the children to the maximum.

The research can be considered successful and effective based on the observation, the content analysis of the reflections of the program and the feedback of the students.

Students actively and enthusiastically participated in each lesson of the program, and a positive change in their knowledge and attitude about Africa was observed in the questionnaire compared to the results measured at the beginning of the project. The student's feedback revealed that thirteen students liked everything about the program. To the question of what they would teach others from the program they named a variety of aspects of the content and emotional elements. The student-highlighted components of the program can be used as a guideline to enrich the methodology of additional sensitization programs and even lessons, to take a new approach.

\section{FUTURE POSSIBILITIES OF THE PROGRAM}

Since 2012, the content and structure of the project have been constantly renewed, keeping pace with changes in the world. The needs of the applicant institutions showed that it is necessary to maintain and develop the program series in Hungarian public education. Based on pedagogical collaborations and feedback, Hungarian educators are happy to use some elements of the program in education. During the questionnaire surveys, both parents and children said that the

Table 2. Relative frequency of African child image

\begin{tabular}{lrrrrrrrrrcrc}
\hline & \multicolumn{8}{c}{ Frequency (\%) } \\
\cline { 2 - 8 } Personality trait & 1 & 2 & 3 & 4 & 5 & 6 & 7 & 8 & 9 & Personality trait & Mean & SD \\
\hline lonely & 20 & 0 & 5 & 0 & 0 & 10 & 5 & 5 & 55 & popular & 6.7 & 3.28 \\
illiterate & 5 & 5 & 5 & 0 & 10 & 10 & 10 & 5 & 50 & literate & 7.0 & 2.59 \\
violent & 10 & 0 & 5 & 0 & 5 & 0 & 5 & 5 & 70 & peaceful & 7.6 & 2.74 \\
helpful & 85 & 0 & 0 & 0 & 0 & 5 & 0 & 5 & 5 & uncooperative & 2.0 & 2.49 \\
strong & 45 & 5 & 5 & 5 & 30 & 0 & 0 & 10 & 0 & weak & 3.2 & 3.28 \\
friendly & 80 & 0 & 0 & 5 & 0 & 5 & 0 & 5 & 5 & unfriendly & 2.2 & 2.51 \\
\hline
\end{tabular}

Note: The personality trait pairs were rated on a 9-point intensity scale from negative to positive property, the maximum of the positive property is 9 , and the more negative it is, the closer it is from 5 to 1 .

Frequency percentages are in italics. 
program provided them with knowledge, helped to develop skills and competencies they had previously had difficulties with, and that the original goal of the project was not to neglect the children participating in the program. compared to the input surveys, the outputs proved that we achieved a positive change in tolerance, sensitivity to minorities, personality development, and development of social competencies among both preschoolers and elementary school students. In addition, the children were able to gain deep knowledge about the society, history, and nature of the African continent.

The continuous change and development of the program also shows that it can be used in many areas, and if obstacles are removed, it can help both teachers and children in new areas. With the help of the African-Hungarian Union (AHU) and the teachers participating in the program, a study competition was organized. The launch of the competition was prevented by the coronavirus epidemic, but the idea of a junior Africa researcher training was born because of the program.

\section{CONCLUSION}

Thanks to technological advances and the advent of the Internet, our world has shrunk to a size that previous generations could not have imagined. Societies today are no longer an isolated, culturally homogeneous community. This holds a number of opportunities, a key element of which is the knowledge and understanding of different cultures and the building of intercultural relations. Business or diplomatic life is unthinkable and unsuccessful without knowing and understanding the culture of the other party, and a basic condition for tourism is to map the cultural habits of customers. But intercultural knowledge plays a key role in virtually any international relationship building.

Young people and children are facing many challenges in a society shaped by globalization. A modern solution to these modern challenges is global education as a concept created by pedagogy. One of the practical implementations of teaching the topics of global education is Ko Nipa Africa! - Teach about Africa! an educational program that seeks to create a realistic image of Africa in the thinking of children living in Hungary by developing their approach to global education, and their social competence with the methods and tools of experiential pedagogy. It also reflects an effort to cultivate tolerance and develop sensitivity to other cultures.

In our study, we hypothesized that due to the ideas about Africa appearing in the Hungarian society, and education system, students and children associate negative concepts with Africa, and their knowledge is one-sided. Research has shown that stereotypes can be observed in all three age groups (e.g., only black people live in Africa who are poor, sick, etc.). Methods examining effectiveness supported that Ko Nipa Africa! - Teach about Africa! changed students' perceptions of Africa in a positive direction, reducing their sense of distance. The aim of the research can be considered successful and effective based on the observation, the content analysis of the reflections of the program and the feedback of the students.

\section{ABOUT THE AUTHORS}

Marianna Kármán, PhD in African Literary and Cultural Studies, has been researching the oral and written traditions, cultural and religious system and practices of the region for about 20 years - primarily in Nigeria. Her specialization includes Islamic studies, intercultural discourse, 
African migration, the process and social context of African neology. Until 2012, she continued her scientific work as a doctoral student at the Doctoral School of Literary Studies at Pázmány Péter Catholic University, and currently as a researcher at the Doctoral School of Security Sciences at Óbuda University.

Nóra Márföldi, holds bachelor’s degree in primary education.

\section{ACKNOWLEDGEMENT}

The revised project was part of the European Union Erasmus+ project, UKids - Youth Start Social Entrepreneurship Programme for Kids (project number 2017-1- AT01-KA201-035062). The author declares no conflict of interest.

All authors had full access to both the design and concept of the study and the interpretation of data.

The authors do not wish to make any additional acknowledgements.

\section{REFERENCES}

Artemisszió Alapítvány (2014). A világ az iskolában - módszertani kiadvány európai és afrikai iskolák közötti iskolai partnerségek létrehozásához [The world at school - a methodological publication for school partnerships between European and African schools]. Budapest: Artemisszió Alapítvány.

Anthropolis Egyesület (2019). A világ az osztályteremben - Útmutató a globális neveléshez [The world in the classroom - A guide to global education]. Budapest: Anthropolis Egyesület.

Cates, K. (1995). Oktatás egy jobb világért: a globális oktatás és az idegennyelv-tanítás kapcsolata [Education for a better world: the relationship between global education and foreign language teaching]. Modern Nyelvoktatás, 4(1), 9-16.

HAND Globális Nevelés Munkacsoport (2008). Globális nevelés, ahogy mi csináljuk: A HAND Szövetség Globális Nevelés Munkacsoport tagjainak bemutatkozása [Global education as we do it: Introducing the members of the HAND Alliance Global Education Working Group]. Budapest: Nemzetközi Humanitárius és Fejlesztési Civil Szövetség.

Havas, P. (1994). A környezeti nevelés széles körü értelmezése [Broad interpretation of environmental education]. Iskolakultúra, 4(18), 54-57.

Hideg, G. (2019). A fair play jelentéstartalmának összehasonlító vizsgálata közép-kelet-európai, kenyai és malajziai fiatalok körében [Comparative examination of fair play among central and eastern european, kenyan and malaysian youth]. In E. Juhász, \& O. Endrödy. (Eds.), Oktatás-Gazdaság-Társadalom (pp. 647-661). Budapest: Magyar Nevelés- és Oktatáskutatók Egyesülete.

Morgan, S. B., Walker, M., Bieberich, A., \& Bell, S. (1996). The shared activity questionnaire. Unpublished manuscript, Memphis. TN: University of Memphis.

Open Access. This is an open-access article distributed under the terms of the Creative Commons Attribution-NonCommercial 4.0 International License (https://creativecommons.org/licenses/by-nc/4.0/), which permits unrestricted use, distribution, and reproduction in any medium for non-commercial purposes, provided the original author and source are credited, a link to the CC License is provided, and changes - if any - are indicated. 